\title{
Social and Historical Environment of the Society of Moscow Artists
}

\author{
Elena Lomova \\ Moscow State Academic Art Institution named after V.I. Surikov \\ Moscow, Russia
}

\begin{abstract}
The article is concerned with the social and historical conditions of forming the Society of Moscow Artists (OMKh), whose members had covered a long way from an epatage art group the Jack of Diamonds to the society standing at the origins of Socialist Realism.
\end{abstract}

Keywords-OMKh; The Jack of Diamonds; futurists; Socialist Realism; art societies in the 1920s and 1930s

\section{INTRODUCTION}

The first half of the $20^{\text {th }}$ century was rich in the landmark events that could not but influence art, one of the most sensual areas of human activity, sensitive to the slightest fluctuations in public life. We can trace their obvious repercussions in art while considering the historical events of the early $20^{\text {th }}$ century.

\section{SOCIAL AND ECONOMIC CONDITIONS IN RUSSIA IN THE PERIOD OF THE OMKH FORMATION}

The development of Russia's society amid the 19th century was gaining momentum. Emerging technologies, railroad construction, capitalism and industry development were spurring state systems into changes. Towards the end of the 19th century, the society was longing for liberal reforms, while the official powers preferred to stay conservative, which raised the social and political tension in the country. The government of Tsar Nicholas II faced the challenge either to keep the existing political system via sanctions or to reform it in line with the developing demands of the mainstream society. Just as the last Russian tsar was inclined to take decisions designed to preserve the existing order, certain political parties, including leftists of the Russian Social-Democratic Labour Party (RSDRP)-later named the "Bolsheviks" that subsequently came to power-saw the things rather differently. The swelling contradictions led to the revolutionary outbreaks in Russia in 1905-1907 and 1917.

At the outset of the century, the world was living in changes that artists had sensed first and tried to translate into their art. Even the revolutionary-minded artists, who formed the Association of Itinerant Art Exhibitions (Peredvizhniki) in 1870 , were unable to imagine the breadth of avant-garde artists' explorations in the 20th century. The turn of the century had been marked by modernistic quest, well represented by the art group Mir Iskusstva (World of Art), including the outstanding Russian painter Igor Grabar, who later became the first chairperson of the Society of Moscow Artists (OMKh). Grabar shared similar vision of art as painters from Mir Iskusstva, who popularized the individualism, the disengagement of art from political and socials issues, and paid particular attention to the legacies of the past and especially to Russia's national cultural traditions. The group's 'leftists', where the "Russian avant-garde" occupied a special place, had shaken even more the conventional assumptions about art, dramatically influencing further development of world art.

Meantime, Russian art continued to shift away from the reality to a non-figurative world, as if not wishing to reflect horrors happening in the country. Whereas the artists from Mir Iskusstva were dipping into the dreams of the past, the avant-garde artists were generally anxious for the future and for getting rid of old art. They were advocating art for the sake of art. Indeed, Avant-garde opposed the conventional art, just as the Bolsheviks opposed the official powers.

\section{ART SOCIETIES AND GROUPS IN THE EARLY 20TH CENTURY}

In Russia, the formation of art societies and associations began way back in the $19^{\text {th }}$ century, set up on the ground of their similar views on the world and art, similar beliefs and the desire to convey to viewers an artist's experiences and idea. The first decades of the 20th century saw a good great many new art societies that rapidly succeeded each other amid turbulent domestic situation: the Russian-Japanese war, World War I, revolution, power shift and the civil war. Amid such hardship, in December 1910 opens the art exhibition "The Jack of Diamonds" (Bubnovy Valet), which overwhelmed public zest, boldness and originality of young artists who were captured by painting, colour and its palette prospecting "Fig. 1". The artists tried to translate their ardency into brisk and texture paintings. Taking in Europe's new art styles of sezannism, fauvism and cubism, the samename art society Jack of Diamonds, established by the artists after the exhibition, had broken through to a new level manifestation of its artistic personality. The group consisted of Pyotr Konchalovsky, Alexander Kuprin, Aristarkh Lentulov, Ilya Mashkov, Alexander Osmyorkin, Vasily Rozhdestvensky, Nadezhda Udaltsova and Robert Falk - the future exponents of the OMKh.

By the revolutionist year of 1917, the growing influence of Suprematist ideas of Konstantin Malevich had led to 
internal conflicts in the art group and eventually to its breakup.

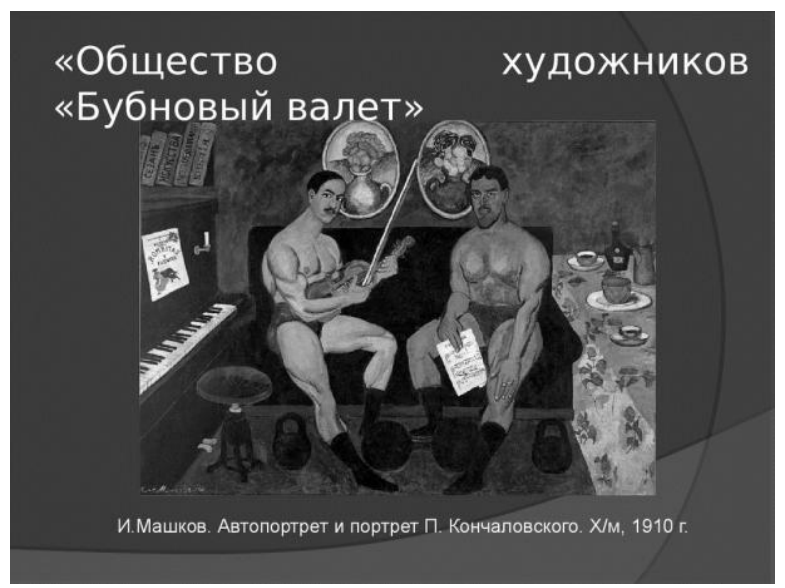

Fig. 1. The Art Society Jack of Diamonds. I. Mashkov, Self-portrait and portrait of P. Konchalovsky. Oil on canvas, 1910.

Avant-garde artists with Malevich at the top, celebrating their victory, spearheaded Russian art after the revolution. Just as the Soviet regime, they were longing for the destruction of old foundations, for progress and mechanization, for the cult of future. They saw art's mission in the crash of the academic art pillars as essentially tsarist, in providing freedom to all art schools on an equal footing, in the attraction of youth and in getting new entrants from working class to join their artistic community. For the moment, the transition of art to a new track required much zealousness, faith and juvenile eagerness that distinguished the avant-garde artists. The new regime also tried to find use of the futurists - the avant-garde artists were called so in the early 20th century - in the area of art design (decoration of sites for holidays, stage and public place setting) and decorative art (improving aesthetic standards of people's living). In the $1920 \mathrm{~s}$, the Bolshevist policy admitted certain artistic freedom in art culture, which contributed to a wide spread of art styles.

These years were marked by active work of Konstantin Malevich, Pavel Filonov, Konstantin Yuon and Boris Kustodiev, each being an unparalleled master in his own fashion. There was an idea flying through the artistic community to turn Moscow into an avant-garde city - the city of the future.

The year 1924 witnessed Vladimir Lenin's death and the communist party bosses' race for the leadership. Internal disarray in the party eased pressure on art. This time had been marked the diversity of artistic associations, whose manifestos were unanimously enunciating the development of a new Soviet art. However, the groups' artistic interpretation of the proclaimed was quite different. The 1920 s saw art' realignment and break-up into formalism and conceptual art. Avant-garde artists, who supported the new regime, came under a heavy criticism. Anatoly V. Lunacharsky, who was appointed First People's Commissar for Education of the RSFSR, repeatedly stressed in his works that the Bolsheviks' loyalty to the avant-garde representatives was the least-evil solution. "I personally gather the progress from the art of the past to the proletarian, socialist art does not run through the futurism, and, if it would be impregnated, at least technically, with certain futurism findings, - probably, to a small extent" [10]. In the same years, the First Commissar of Education formulated problems in the art issues:

- Public information and advocacy work through art;

- Assistance in the identification of an independent working-class art and, along with it, of a folk art;

- Popularization of the masterpieces of the past, even though not directly propagandistic or agitational.

Avant-garde was unfit for the achievement of the assigned mission since its language was strange to workers and peasants that composed the major audience of the working-class community. The futurists were going too far in their drive to capture art and were unable to meet the realworld challenges. The fledgling country had chosen its course and painters, poets and other artists stood before the choice either of yielding to the set rules, betraying their avant-garde, or of pressing their point on art, which they found dramatically difficult to do in the Soviet state by the 1930s.

At the outset of the 20th century, artists realized their capacity of self-expression. Just as Russian artists were strongly influenced by modern trends, Russia's art, which was just spreading its wings and had just tasted the diversity of styles and techniques, was forced to change headily amid the change of power. After beating the political in-fighting, Stalin had consolidated his power. Private and capitalist enterprises dissolved, the year 1928 headed for industrialization and ushered in the first five-year industrial plan.

By the 1930s, with the establishment of the totalitarian regime, the enforcement actions toward public increased dramatically. The year 1929 witnessed the start of the campaign against the avant-garde, press attacks and mass dismissals. The avant-garde adherents, who rose to power after the revolution, started to lose their influence. Among the arrested were the art expert N.N. Punin and the friendly to the avant-garde V.E. Meyerhold (executed afterwards). The fortunes of avant-garde artists were in question. The 1920s and especially the 1930s became the most adverse for artists who started their career way back in the Czarist-era. They had to bid for government contracts and grants- such was the background of the formation of new associations of artists and writers.

In the meantime, former members of the Jack of Diamonds intended as before to serve the cause of revolution, but any dialogue with the authorities was impossible. The Occidental art (Cezanne, Derain, Picasso) that influenced their works, was proclaimed as foreign to 'Soviet' art and invited strong criticism for being close to 'bourgeois' movements. The new art society Moscow Painters, existing in 1925, marked the first attempt of the artists to get together once more. Among its founders, there were the already known for the Jack of Diamonds Konchalovsky, Kuprin, 
Lentulov, Osmyorkin, Rozhdestvensky and Falk. An important point was the affiliation with the already mature team of Igor Grabar, Alexander Drevin and Nikolai Shestakov, who also joined OMKh afterwards. The society's manifest explicitly proclaimed it was "against its former allies in the leadership at the People's Commissariat of Education - the supporters of abstract and industrial art" [12]. The manifest that acknowledged submission to the Soviets, did not change the artists' fundamental nature, united by the reliance on the art traditions of Cezanne and of artistic freedom. Moscow Painters did not last, however. The attacks of criticism and growing pressure on the part of the Association of Artists of Revolutionary Russia, which was the most powerful group of that time, took their toll. After the group's breakup, its members wandered around at different societies and groups in an attempt to strike a balance between their personal art principles, developed before the revolution, and the new national interests.

Grabar, Konchalovsky, Lentulov, Mashkov, Osmyorkin, Rozhdestvensky, Falk and others had already become mature masters by that time and their affiliation with different art groups had little influence on their personal style; more likely, their art was forming choices of the new generation. In 1925, Osmyorkin, Kuprin and Konchalovsky joined the formal, in terms of its objectives, art group Genesis (Bytiye) "Fig. 2".

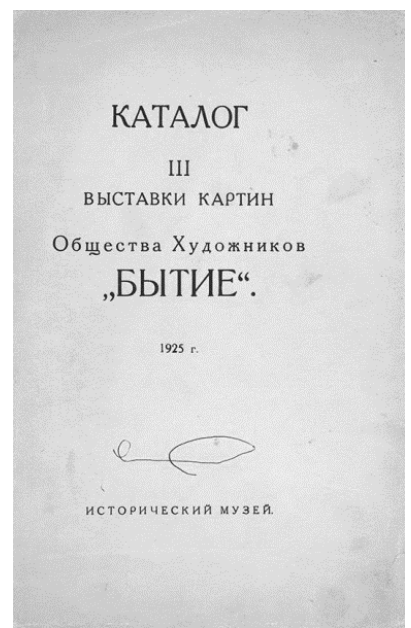

Fig. 2. Catalogue of the $3^{\text {rd }}$ Exhibition of the Genesis.

The art expert Vitaly S. Manin, speaking on the art group Genesis, concludes, "Prior to the year 1928, exhibitions were characterized by washiness, but for the works of $\mathrm{P}$. Konchalovsky, A. Osmyorkin, A. Kuprin" [11]. Some part of the art group, led by Alexander Osmyorkin, soon split and formed new group called the Wing (Krylo). The art critic I.E. Khvoinik, called the rift a 'family dispute'. There were no social implications in the new group's works. The Wing displayed loyalty to simple subject matters, landscapes and still life. Its talented leader Osmyorkin could not have the situation changed, and this did not let the art group survive under the Soviets.

\section{FORMATION OF THE SOCIETY OF MOSCOW ARTISTS}

After Moscow Painters' dissolution, some of its former members looked towards AKhRR (the Association of Artists of Revolutionary Russia). In 1926, a discussion evolved around the affiliation with it of the Jack of Diamonds artists, whose works offered a charge of pure fresh look, vivid art and drive, which the professionally sound AKhRR paintings evidently missed. Some of the AKhRR members were opposed to such affiliation with formalistic, in their opinion, artists. Nonetheless, the Association's central secretariat voted for the affiliation with the ex-members of the Jack of Diamonds. Still, the new members of the AKhRR never teamed up with the rest and the disputes around their artistic methods had been nowhere near exhausted. The 'new recruits' finally withdrew from the Association some time later.

The former members of Moscow Painters had more in common with each other than with the art groups and associations they tried to enter. By 1928, they decided to get together once again and to found the Society of Moscow Artists, wherein the already established core of the older generation artists was reinforced by young blood from the art groups Wing and Makovets. The very title of the Society, twisted into the abbreviation OMKh, pays tribute to the Soviets that were gravitating toward imposing abbreviated terms. The group's charter and manifest summed up its freedom from formal explorations and from support of official policy in art "Fig. 3".

As a public service, the OMKh produced posters and postcards, carried out decorative design orders. The group's youth work was one of the calls of the times. Just like at the AKhRR, the OMKh also had a youth organization, the members of which were expected to adopt methods of the senior masters. The elder generation of the OMKh was unable to catch up with changing social trend and their complex vision became unwanted. New social environment demanded an ideological popular art that speaks an explicit language of realism.

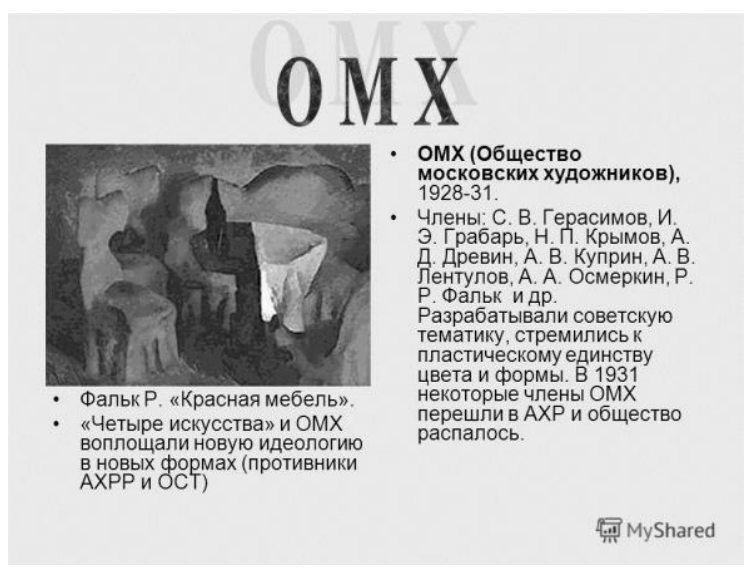

Fig. 3. The OMKh. Falk R. Red Furniture.

In 1928, the group held two reporting exhibitions. It is easy to trace from their catalogues the main theme of the OMKh artworks. Their authors preferred neutral themes, such as still life, landscape or portrait, but there were also 
artworks imbued with the Soviet idea. Sergei Gerasimov presented at the 1928 exhibition his works addressing a country life ("Blacksmiths", "Woman with a rooster", "Country scene" etc.). Ivan Zavyalov ("Dull day in a village", "Village construction", "At a log hut" etc.) and Nikolai Shestakov ("A country girl", "The old peasant") addressed the same issue as well. Rare art works, consistent with the latest social demands, could be found in R. Falk's "Executive meeting"», S. Petrov's "Attacking Red Army man" and V. Sherishev's "Workers column".

By the time of the second exhibition, hosted in the Moscow Recreation and Culture Park in 1929, the art group had underwent certain reforming-Aristarkh Lentulov replaced Igor Grabar as the OMKh chairperson; its core included the younger generation of the group (OMKh-2) with socialist orientation. Abram Efros, making an overview of the exhibitions for the weekly Literaturnaya Gazeta, remarks: "They are honest in their development of strength and are sincerely trying to move with own country and own epoch. They know, for instance, that Russian art's provincialism can be disposed of by the means of Occidental vaccination. That is why they are careful with their past, with the Jack of Diamonds that had fostered them. They are developing, transfiguring, intercrossing its original 'sezannism' with the Russian realistic tradition and are getting fair results" [8]. The critic is generally positive about the exhibition, the OMKh art works made viewers relax and enjoy art, and still, in the spirit of sketches of those years, the author could not but criticize the slothful development of the Soviet theme.

Despite the painful process of the artists' endeavour and movement towards the socialist realism, the number of artworks elaborating upon the theme of building communism was growing. Among those were "Communist entrants of 1919" by Osmyorkin, a series about Donbas mineworkers painted by Petrov, "Landscape with a factory" of Rybnikov, "Evening workers' school at home" and "Workers' school goes" of Shemyakin, and Shestakov's "Conversation of demobilized Red Army man with village men in a village reading room". Although the masterpiece of Aristarkh Lentulov "Stepan Razin" does not refer directly to the communist theme, its pathos and grandeur are close to the socialist realism as well. Most of the art works at the group's exhibitions, however, were etude and offered a neutral subject theme. Such strategy let the OMKh stay afloat for a while, and be one of the largest associations of the time. The Association did not come close to the Soviet authorities, though.

The Society of Moscow Artists had made one of the biggest art groups of the 1920s and 1930s "Fig. 4". The press mentioned the OMKh among the art groups 4 Arts, OST and the AKhR (AKhRR until 1928). These leading art groups represented Russia in international exhibitions, including an art fair in New York in December 1928, an exhibition in Riga, aimed to improve ties with Latvia, in November 1929 and in another one in Stockholm in March 1930. The exhibitions, representing the Soviet state, were expected to improve the young nation's ties with other countries and featured the OMKh, by its concept, as a Soviet art society.

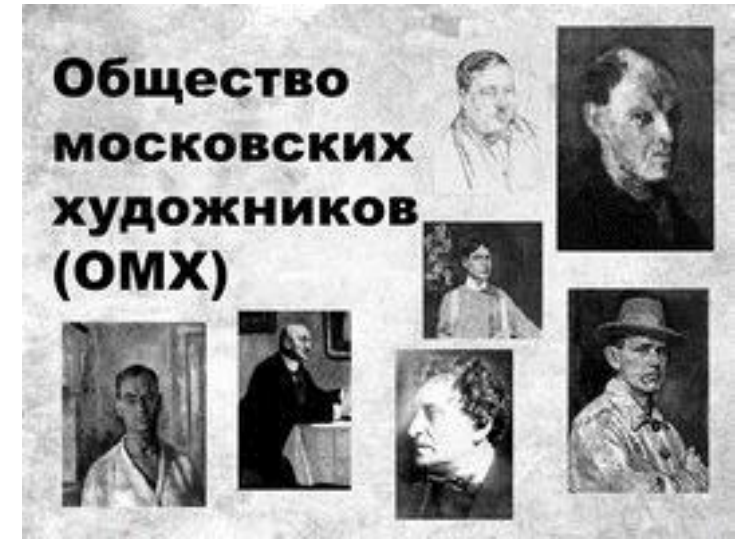

Fig. 4. Society of Moscow Artists (OMKh).

A.V. Lunacharsky remarks in his works that the Soviet state needed artists capable of performing a complete, realistic work with a thoughtful composition and an explicit idea. The socialist realism, destined to show the beauty of industrial world and better tomorrow of the moving onward nation, wins the internal struggles between the artistic styles.

\section{CONCLUSION}

Each art group had made its own way from the inception to dissolution. Some of them had reached their limits and were replaced by new styles, new fashion. The OMKh, offering a breath of pure painting, was long balancing between the art familiar to its founders and the socialist call. The end to this art society was put by the resolution of the Central Committee of the All-Union Communist Party "On Reorganization of Literary and Artistic Organizations", issued on April 23, 1932, upon which all existing art organizations and groups were closed, while all Moscow artists were brought together under the single Moscow Union of Soviet Artists. In the article Thousand canvases for the newspaper Sovetskoye Iskusstvo on November 4, 1932, M. Arkadiev refers to the OMKh among other art groups in the past tense. Their artworks, exposed at the retrospective exhibition that gathered the masters of the first decades of the post-Revolution era, already belonged to the Soviet history.

Politicians of the $20^{\text {th }}$ century recognized the power of art for mainstreaming socialist ideas. This required an intelligible art for all social groups, conveying a loud and clear message. The realistic art styles, such as the Peredvizhniki movement (The Wanderers) in the late $19^{\text {th }}$ century, had already addressed ordinary Russians' living and work. The socialist realism of the $20^{\text {th }}$ century, addressing the same subjects, had a more powerful social leverage devised by the so-called 'formal' art.

Unlike art of the $19^{\text {th }}$ century that illustrated ordinary Russians' life by means of classical compositions, reserved colour palette and careful drawing, the Soviet art had already absorbed all avant-garde findings of the early century. Artists, who were adherent to the Socialist art, retained the selection of avant-garde artistic devices: preference of large colour masses, open colours, the greater composition freedom, a 
bold free stroke - that increases the effect of the $20^{\text {th }}$ century Soviet realism on the viewer as compared to its precursor. Art no longer encourages reflecting on the people's destinyit propagandizes, openly calls for changes, displaying life not as it is, but as it should be in the new state.

The historical events of the first half of the $20^{\text {th }}$ century had a great impact on the OMKh artists' evolution. Despite the challenging political and social situation, forcing to adapt oneself to the new environment, the OMKh members continued their figurative search and did much to develop a new artistic language. Working with colour and facture of the piece, they had developed a novel way of conveying the bright attitude to life, which all heroes of socialist artworks will be exuding later, looking ahead to a bright new dawn.

\section{REFERENCES}

[1] Exhibition of artworks of the Society of Moscow Artists OMKh, V.: Mosgublit No.5182, 1928, p. 27.

[2] I.E. Grabar, My Life, Automonography, L.-M.: Iskusstvo, 1937, p. 375.

[3] History of Russia: textbook /A.S. Orlov, V.A. Georgieva, T.A. Sivokhina, 3rd ed., revised and enlarged, M.: TK Velbi, Publishing Prospekt, 2008, p. 528.

[4] History of Russian and Soviet art, Editor D.V. Sarabadianov, M.: 1979.

[5] The exhibition catalogue of the "Society of Moscow Artists" with the articles of Ign. Khvoinik and N.M. - M. Park of Culture and Recreation: Glavlit No. A38728, 1929, p. 106.

[6] M.S. Lebedyansky, Russian painting of 1920-1930, Sketches, M.: Iskusstvo, 1999, p. 144.

[7] Literaturnaya Gazeta No. 6 [Newspaper], M.: 1929, p. 3.

[8] Literaturnaya Gazeta No. 11 [Newspaper], M.: 1929, p. 3.

[9] A.V. Lunacharsky, About art: in two volumes, Vol. 2 (Russian Soviet art), M.: Iskusstvo, 1982, p. 391.

[10] Ibid. p. 88.

[11] V.S. Manin, Glimpses of history of artistic associations of Moscow and Leningrad (1921-1932): Thesis for PhD in History of Arts: 17.00.04/ Manin Vitaly Serafimovich, M.: MGU, 1973, p. 89.

[12] Ibid. p. 96.

[13] National history of the XX century, Textbook, under the editorship of Prof. A.V. Ushakov, M.: AGAR, 1997, p. 496.

[14] Sovetskoye Iskusstvo No. 50-51 [Newspaper] - M.: 1932, pp. 1, 7.

[15] Art since 1900 / Hal Foster, Rosalind Krauss, Yve-Alain Bois, Benjamin H. D. Buchloh. - United Kingdom: Thames \& Hudson Ltd, 2004, p. 704. 